\title{
Podmiotowość istoty ludzkiej w procesie rozwoju i transformacji - refleksja historiozoficzna
}

Najważniejsze i najbardziej dociekliwe pytanie, jakie człowiek stawiał sobie niezmiennie i które ustawicznie będzie ponawiał, to pytanie o swe pochodzenie i rozwój od chwili pojawienia się istoty ludzkiej na tej planecie, którą nazwał on Ziemią.

Już Huxley nazwał ten problem najważniejszym ${ }^{1}$, podobnie Häckel ${ }^{2}$. Wracał do tego w XX wieku również Karl Jaspers ${ }^{3}$. Nie ma żadnego mitu, żadnej sagi etnicznej, żadnej filozofii, która nie nawiązywałaby do myśli o genezie istoty ludzkiej. Skąd pochodzi człowiek, jak się stawał istotą ludzką, gdzie znajduje się obszar jego poczęcia, jak przebiegał dalszy rozwój wiodący do duchowej wielkości, szlachetności, które wyróżniają go od świata zwierząt? Człowiek stale pozostaje zagadką, która tkwi między zwierzęciem a istotą boską i nadal ta zagadka jest przedmiotem kolejnych wyzwań badawczych.

Poprzez tysiąclecia ludzkość posiadała niejasne tylko wyobrażenia świtu swego człowieczeństwa, jednostka ludzka bowiem nie posiada własnych wspomnień swych narodzin. Społeczeństwo ludzkie pragnie jednak znać przebieg tego

\footnotetext{
* Profesor, Uniwersytet Łódzki, Wydział Studiów Międzynarodowych i Politologicznych, Katedra Systemów Politycznych.

1 Th.H. Huxley, Stanowisko człowieka w przyrodzie, Warszawa 1874.

2 E. Häckel, Die Anthropogenie, Leipzig 1874.

3 K.Th. Jaspers, Vom Ursprung und Ziel der Geschichte, Basel 1949.
} 
procesu, ponieważ stawanie się zawiera w sobie świadomość celu, bez czego egzystencja ludzka jest nie do pomyślenia. Człowiek nie może żyć bez świadomości kierunku swego życia, bez wartościowania swego istnienia, co jak światło rozjaśnia jego drogę życiową. Ta droga musi zawierać początek i koniec, które pozostając we wzajemnym związku, są jakby złączone klamrą bytu, stanowią określone punkty biegunowe kroczenia człowieka przez padół ziemski. Cel wyrażający wartość, treść życia, sens istnienia jest zawsze związany z przyszłością, która jednak pozostaje jakby w głębokim cieniu. Natomiast przeszłość zawiera w sobie to, co się działo faktycznie, było rzeczywistością, zawiera w sobie takie procesy jak pochodzenie. Dlaczego więc człowiek posiada tak niewiele wiedzy o swej genezie? Jak może przewidywać swą przyszłość i zdążać do określonego celu, skoro nie ma dostatecznej wiedzy o przeszłości?

Mesjanistyczna nadzieja wywodzi się z prabytu łączącego się z wyobrażeniem raju i stale jest oczekiwaniem osiągnięcia przez istotę ludzką takiego stanu, w jakim rzekomo pierwotnie ona się znajdowała - w stanie duchowego człowieczeństwa. Skąd więc wywodzą się ułomności ludzkie - niegodziwość, zakłamanie, zdrady, obłuda czy zły duch? Czyż więc byłyby to cechy immanentne, nadane pierwotnie, czy też powstały raczej jako odszczepieństwo od pierwotnego bytu - bytu prawdy, autentyczności, honoru, dobroci? Jakim wobec tego był człowiek w swych początkach? Znów więc pojawia się pytanie o prabyt, o Adama.

Nie jest to pytanie zadawane wyłącznie z perspektywy scjentystycznej, nauka bowiem jest stosunkowo młodą przestrzenią intelektualną. Mamy tu raczej do czynienia z prapytaniem zadawanym przez człowieka od pradziejów o istotę egzystencji ludzkiej - o jego wyjątkowość poznawczą.

Wielkie, starożytne cywilizacje najwcześniej usystematyzowały refleksję na temat człowieka. Sumerowie, Egipcjanie, Chińczycy stworzyli m.in. mity o pierwotnym człowieku, który istniał od początku i żył rzekomo w harmonii ze światem, w zgodzie ze zwierzętami, w bezpieczeństwie i dobroci serca.

Babilońskie informacje zawarte w sumeryjskich tekstach mówią o miejscu zamieszkiwania bóstw, gdzie istnieje boskość życia oraz piecza nad stadami i zbożami. W eposie o Gilgameszu, który powstał w trzecim tysiącleciu - Enkidu, nazwa ta odnosi się do człowieka - żyje on w szczęściu i zadowoleniu razem ze zwierzętami. Wraz z gazelami spożywa rośliny polne. Razem ze zwierzyną pije wspólnie z wodopojów, wspólnie swawoli we wzburzonych falach wodospadów ${ }^{4}$.

I. Diakonow, Opowieść o Gilgameszu, [w:] Wschód Starożytny, W.W. Struwe (red.), Warszawa 1956, s. 133-138. 
W jednym $\mathrm{z}$ egipskich tekstów odkrytych w piramidach, uchodzących za najstarsze, zawarty jest przekaz, iż pierwotnie zadowolone były wszystkie bóstwa zarówno w niebie, jak i na ziemi. Szczęśliwe były też bóstwa południa i północy, zachodu i wschodu, bóstwa okręgów i miast, człowiek zaś żył z bóstwami i zwierzętami w szczęśliwości i w zgodzie ${ }^{5}$.

W myśli chińskiej - co zawarte jest w przekazach Ji Ginga (Yi King) - egzystencja ludzka oparta miała być pierwotnie na myślistwie i rybołówstwie i pozostawała w harmonii ze światem. Ludzie egzystowali we wzajemnym związku i zgodzie ze zwierzętami, zaś Adama tej epoki zwano Paotti. Żył szczęśliwie, nie znał trosk ani zmęczenia, posiadał dostatek żywności, był otoczony zwierzyną i żył z nią wspólnie. Ona była dostarczycielką pożywienia, ubioru i niezbędnych narzędzi z kości i rogu'

Platon potwierdza te mity o pierwotnie istniejącym raju w księdze o państwie $^{7}$. Myśl ta żywa jest u Hezjoda ${ }^{8}$, pojawia się też zarówno u Izajasza ${ }^{9}$, jak i u Wergiliusza ${ }^{10}$.

Uporczywie utrzymuje się myśl o powrocie pierwotnej harmonii, gdzie ludzkość przeżywać będzie nowy, złoty wiek, powróci zgoda, szczęście, wspólne obcowanie, okres pokoju. Prorok Izajasz o tej nadchodzącej epoce mówi: wilk z barankiem paść się będą społem, lew jako wół plew jeść będzie, a wężowi proch będzie chlebem jego, nie będą szkodzić ani zatracać się. Zjawi się Mesjasz i świat odnowi ${ }^{11}$.

Również współcześnie funkcjonują idee o niebywałej sile, które dostarczają ludziom złudnych, wręcz mitycznych koncepcji, archetypów o niewyobrażalnym ładunku emocjonalnym dotyczących sensu i celu istnienia.

Dziewiętnastowieczni myśliciele wierzyli w możliwość wydobycia tych mitów z nieprzewidywalności i przeobrażenie ich w logiczne myślenie, które nazwano naukowym socjalizmem. Nie jest też więc przypadkiem, że właśnie ta idea pozostaje w związku z pierwotnymi wyobrażeniami egzystencji ludzkiej, z prastarymi mitami i sagami.

Żadna - teoria monetarna - jak i żadna narodowo-ekonomiczna konstrukcja myślowa - nie posiada takiej siły do aktywizacji mas ludzkich jak mesjanistyczny socjalizm, który w ciągu XIX i XX wieku wykazywał dynamiczną siłę. Była ona tak skuteczna, że podzieliła współcześnie żyjącą ludzkość na dwa

\footnotetext{
E. Meyer, Geschichte des alten Ägyptens, Berlin 1887, s. 8-22.

L. Pozdniejewa, Mity Chińczyków starożytnych, [w:] W.W. Struwe (red.), op. cit., s. 208-214.

Platon, Państwo prawa, Kęty 1999, s. 269.

8 Hezjod, Prace i dnie, Wrocław 1952, s. 110.

9 Iz $1 ; 8 ; 65,25$.

10 Wergiliusz, Bukoliki, Georgiki, Wrocław 1953, 6 ekloga.

11 Iz 65, 25.
} 
wrogie obozy, które jeszcze bardziej zajadle stawały przeciw sobie niż to czyniły w przeszłości i czynią w teraźniejszości wskutek wojen religijnych.

Pytanie o prabyt człowieka wtargnęło też w centrum naszych dni i demonstruje się współcześnie w postaci eksodusu azjatycko-afrykańskiej ludności w głąb Europy. Jest to w rzeczy samej kolejna wędrówka ludów, jakie zdarzały się przed tysiącami i setkami lat. Łączy się to zjawisko także z procesem konfrontacji cywilizacji - jak nazwałby to Huntington ${ }^{12}$.

Człowiek współczesny przeżył także dwie straszliwe wojny światowe. Pierwsza trwająca od roku 1914 do 1918 pochłonęła 20 milionów zabitych, druga od 1939 do 1945 pochłonęła ich 50 milionów. Około 10 milionów ludzi przebywało w obozach koncentracyjnych, tylko w Auschwitz zginęly cztery miliony, we wszystkich zaś obozach zginęło sześć milionów uwięzionych. Ta wielomilionowa masakra wydarzyła się w Europie, którą ludzkość uważa za najbardziej cywilizacyjnie rozwiniętą część świata i która rości sobie pretensje do tego, aby wskazywać innym narodom świata kierunek postępowego rozwoju.

Do niedawna trudno było spotkać takiego człowieka, który by nie był zagrożony zagładą i któremu by w czasie tych dwóch wojen, a także często między wojnami, śmierć nie stawała w oczach. Byt Europejczyków, a jakże często także mieszkańców pozaeuropejskich części świata, stawiany był przez cały wiek XX przed ustawiczną obawą zagrożenia życia, przed uczuciem zwątpienia i załamania, przed udręką i zgubą. Trony cesarzy, królów i książąt były powalane, walki klasowe zostawiły głębokie rany. Okrucieństwa stosowano jak nigdy dotąd, tortury, rozmyślnie zadawane cierpienia, mordy jeńców, okaleczenia - literalnie wszystko, co dotąd z dreszczem przerażenia czytano o torturach średniowiecznych, tylko jeszcze okropniejsze, bardziej perwersyjnie wymyślne. Całe miasta obrócono w proch i pył, w nędzę, w ból i łzy, zwątpienie, lęk i zgrozę.

W takich czasach, bardziej niż w wyciszonych okresach, żywe się staje wieczne pytanie: czym jest człowiek, jak to możliwe, że istota ludzka jest zdolna te okropności pomieścić w sobie? Czymże więc on jest, jeżeli tę przepastność zła może w sobie zawrzeć? Człowiek staje zatem przed sobą samym przepełniony przekleństwami, załamany, wątpiący w siebie samego. $Z$ obrzydzeniem postrzega swoją nikczemność - gdzież się podziała ta boskość, która rzekomo w nim jest?

Takie chwile zmuszają do pytania o sens bytu człowieka, o jego wartość czy raczej brak wartości. Budzi się w nas wtedy konieczność skierowania swego spojrzenia, intensywniej niż $\mathrm{w}$ minionych epokach, na człowieka pierwotnego. Zwraca to naszą uwagę na czas, kiedy człowiek rzekomo był jeszcze

12 S.P. Huntington, Zderzenie cywilizacji i nowy kształt ładu światowego, Warszawa 2001. 
prostolinijny, nie zepsuty, nie opanowany obłąkańczymi ideami, nie wprzężony w koleiny samolubnego myślenia, nie ogarnięty popędem walki przeciwko innemu człowiekowi, do czasów, kiedy w istocie ludzkiej kształtowało się człowieczeństwo. Pytania takie wypływają w trudnych okresach historii, stawia je chrześcijaństwo, kiedy myślimy o Adamie, o jego popadnięciu w niełaskę Opatrzności, co wyartykułował już w XIII wieku Roger Bacon ${ }^{13}$. Pytania te nurtowały także myślicieli renesansu i reformacji - Erazma z Rotterdamu ${ }^{14}$, Melanchtona ${ }^{15}$, Hugona Grotiusa ${ }^{16}$.

$\mathrm{W}$ czasach rewolucji francuskiej problem ten stawał jako centralny punkt refleksji intelektualnej. Formułowano go jako pytanie o prawa ludzkie, o naturalne samostanowienie człowieka w stosunku do innych ludzi, w stosunku do jego pierwotnych skłonności.

I tak, przestrzeń refleksji Jean-Jacques’a Rousseau została całkowicie zmajoryzowana tym problemem. Ustawicznie powraca on do człowieka naturalnego $\mathrm{w}$ jego pierwotnej egzystencji ${ }^{17}$. Istotna jest $\mathrm{w}$ tym względzie rozprawa o pochodzeniu i podstawach nierówności ${ }^{18}$. Rousseau rozpoczął ją od rozróżnienia między dwoma rodzajami nierówności - naturalną (przyrodzoną) i sztuczną. Nierówność naturalna wynika $\mathrm{z}$ różnic $\mathrm{w}$ sile, inteligencji i z przyrodzonych cech człowieka, natomiast ta druga - nazwana przez Rousseau sztuczną - wynika z praw rządzących społeczeństwem. I ją właśnie starał się Rousseau wyjaśnić, rekonstruując najwcześniejsze fazy ludzkiej egzystencji na ziemi. Wysunął tezę, że pierwszy człowiek nie był istotą społeczną, lecz całkowicie samotną. Pod tym względem zgadzał się z opisem stanu natury Thomasa Hobbesa ${ }^{19}$.

Jednak w przeciwieństwie do pesymistycznych poglądów Hobbesa dotyczących warunków życia pierwszych ludzi, którzy mieli wieść żywot „nędzny, wstrętny, brutalny i krótki", Rousseau twierdził, że pierwszy człowiek - choć niewątpliwie samotny - był jednak zdrowy, szczęśliwy i wolny. Ludzkie zło - twierdził dalej - pochodzi z czasów powstawania społeczeństwa. W ten sposób uwznioślił naturę, obarczając społeczeństwo winą za istnienie zła. Stwierdził, że namiętności powodujące zło niemal nie istnieją w stanie naturalnym, lecz zaczynają powstawać wraz z formowaniem się społeczeństw. Wysunął tezę, że życie społeczne rozpoczęło się, gdy człowiek zbudował pierwsze domostwa,

13 S. Swieżawski, U źródeł konfliktu nowożytnego przyrodoznawstwa z filozofią scholastyczną, Lublin 1948.

14 J. Domański, Erazm i filozofia, Wrocław 1973.

$15 \mathrm{Ph}$. Melanchton, Epitome doctrinae christianae, Wittenberge 1524.

16 A. Lysen, Hugo Grotius: Essays on His Life and Works, Leyden 1925.

17 B. Baczko, Rousseau - samotność i wspólnota, Warszawa 1964.

18 J.J. Rousseau, Rozprawa o pochodzeniu i podstawach nierówności, Warszawa 1956.

19 F. Tönnies, Tomasz Hobbes, Warszawa 1903. 
co doprowadziło do wspólnego mieszkania mężczyzn i kobiet, a to z kolei stworzyło zwyczaj życia w rodzinie i wśród sąsiadów. Wspólnoty sąsiedzkie - jak nazwał tę fazę Rousseau - były w istocie złotym wiekiem ludzkiej historii. Delikatna, miłosna namiętność dała jednak początek destrukcyjnej namiętności - zazdrości. Sąsiedzi porównywali swoje umiejętności i osiągnięcia, co stało się pierwszym krokiem do nierówności i początkiem zła. Ludzie zaczęli żądać uwagi i szacunku, ich niewinna miłość własna zamieniła się w grzeszną pychę, bowiem każdy chciał być lepszy od innych. Pojawienie się własności stanowiło kolejny krok ku nierówności, ponieważ wprowadziło konieczność tworzenia praw i rządów chroniących własność. Spostrzeżenia te inspirowały późniejszych rewolucjonistów, takich jak Marks czy Lenin, choć sam Rousseau nigdy nie twierdził, że można zawrócić bieg wydarzeń historii, zaś powrót do „złotego wieku” był według niego mrzonką.

Niemiecki ruch intelektualny Sturm und Drang powstawał w zupełności pod silnym wpływem Rousseau. Filozofowie, myśliciele i twórcy, tacy jak Kant, Jefferson, Herder, Goethe, Schiller, przejęli rozstrzygające impulsy od niego.

Szczególnie Schiller rozwija żywotnie koncepcje Rousseau. W swej rozprawie Co nieco o pierwszym społeczeństwie ludzkim utrzymuje, że:

[...] tak jak rośliny i zwierzęta, tak i człowiek został stworzony od pierwocin swego bytu. Sukcesywnie też zaczął się rozwijać jego rozum. Ponieważ natura była dla niego łaskawa, troszcząc się o niego i działając na jego korzyść, toteż on sam mniej sił zużywał na zapewnienie swej egzystencji i bez przeszkód rozwijał swój umysł, nierozpraszany żadnymi troskami skupiał się na doskonaleniu swych narzędzi, swej mowy oraz subtelnym strojeniu swego intelektu. Jego pogodny umysł ogarniał wszystkie zjawiska bezinteresownie i czysto, wprowadzając je nieskalane i szczere do swej pobudzonej pamięci. Delikatnie i z uśmiechem przebiegała kreacja człowieka, on zaś sam wzmacniał spokojnie swoje siły do walki, która go czekała.

Zaraz po tych z romantycznym uczuciem sformułowanych zdaniach nazywa Schiller pradziejowego człowieka najszczęśliwszym i najbardziej uduchowionym ze wszystkich zwierzą ${ }^{20}$.

Pytanie o sens ludzkiego istnienia i kreacji pramyślącego człowieka nie milkło nigdy, pojawia się ono u Fichtego, Schlegla, Schellinga i wkracza także w czasy współczesne, nie tracąc nic na aktualności.

Zagadnienie pradziejów jest nieustannie poruszane tak przez filozofów, jak i przedstawicieli pokrewnych dyscyplin naukowych. Tam jednak, gdzie bledną filozoficzne rozważania, zaś źródła pisane milczą - decydującej odpowiedzi dostarcza zbadanie warstw ziemnych łopatą archeologa. Żywe zainteresowanie współczesnego społeczeństwa badaniami archeologicznymi, które odkrywają

20 F. Schiller, Etwas über die erste Menschengesellschaft, Jena 1790. 
drogi rozwoju pierwotnego człowieka budzi duży popyt na publikacje, które podejmują tę tematykę. Niektóre pozycje stają się bestsellerami, zaś nakłady sięgają setek tysięcy egzemplarzy, przekładane też są na wiele języków ${ }^{21}$.

Jednym z istotnych czynników wzrostu znaczenia poznawczego archeologii wydaje się stosunek sztuki współczesnej do stylizowanej, abstrakcyjnej sztuki prahistorycznej. Styl sztuki określonej epoki jest zazwyczaj najgłębszym, najdoskonalszym z możliwych środkiem wyrazu. Odczucia zarówno emocjonalne, jak też indywidualne i społeczne, przeżywane w określonym czasie, odzwierciedla obok filozofii, najdoskonalej upostaciowienie w sztuce. Podczas gdy filozofia ujmuje istotę określonego czasu poprzez przeniknięcie myślą, mentalnie, sztuka wyraża to w kształcie, $\mathrm{w}$ formie.

I tak, sztuka abstrakcyjna jest wyrazem formy zapoczątkowanej w malarstwie europejskim drugiej połowy XIX wieku i stopniowej rezygnacji z tradycyjnej koncepcji sztuki mimetycznej. Proces ten, narastając od impresjonizmu, przygotował grunt dla rozwoju sztuki stylizowanej i abstrakcyjnej. Jej istotę stanowi - jak uważa Kandinsky - uchwycenie duchowej treści przedmiotu, która wypełnia formę ${ }^{22}$. Ta sztuka współczesności łączy się przedziwnie z tym, co najbardziej wewnętrzne w sztuce prehistorycznej późnego plejstocenu i wczesnego holocenu, a następnie w neolicie i epoce brązu. Dotyczy to zarówno plastyki, jak i malarstwa, które to dziedziny sztuki wykazują tak wyraźne zbieżności, iż nie można tego wytłumaczyć czystym przypadkiem i jest rzeczą oczywistą, iż to, co pierwotne, wpływa na to, co późniejsze.

Prehistoryczne malarstwo abstrakcyjne, podobnie jak grawerunek i plastyka, ujawnione zostały przez badania archeologiczne XVIII i XIX wieku. Sztuka ta jednak nie wywarła wówczas na współczesne społeczeństwo istotnego wrażenia. Odstawiono te dzieła sztuki do regałów w przepastnych magazynach muzealnych, ponieważ tylko nieliczni poświęcali im należytą uwagę.

Każda zmiana w rozwoju sztuki powstaje na skutek pojawienia się nowego impulsu stylistycznego z jednej strony oraz gotowości przyjęcia innowacji z drugiej. I tak, np. barok wykrystalizował się m.in. na skutek infiltracji elementów tradycyjnej sztuki indyjskiej. Świadczą o tym chociażby cebulowate hełmy wież kościelnych znacznej części Europy Południowo-Wschodniej i Środkowej. To nie tylko wpływ sztuki islamu i Bizancjum, ale pierwotny, hinduski, co wyraźnie

${ }^{21}$ J. Kleibl, Skad przychodzisz, Adamie?, Katowice 1981; R. Moore, Skamieniałymi śladami człowieka, Warszawa 1966; Z. Kosidowski, Gdy Słońce było Bogiem, Warszawa 1956; F. Weremiej, Śladami zagubionych ogniw, Warszawa 1977; Z. Bukowski, K. Dąbrowski, Świt kultury europejskiej, Warszawa 1972; The Origins of Europe, D. Collins (red.), London 1975; G. Bibby, Faustkeil und Bronzeschwert, Hamburg 1957; V.G. Childe, The Dawn of European Civilization, London 1950.

22 J. Białostocki, Sztuka cenniejsza niż złoto, Warszawa 1974. 
dostrzec można, obserwując zwieńczenia wież m.in. w Delhi czy Agrze. Dalszy wpływ uwidacznia się w zwojowej ornamentyce zdobiącej wyroby meblowe, a zarazem występującej w plastyce i malarstwie. Jest to wyraźne naśladownictwo wzorów indyjskich, które wtargnęły wtedy do Europy. Istotną przyczyną szerzenia się tych wpływów była ekspansja europejska, szczególnie brytyjska, której spiritus movens stała się Kompania Wschodnioindyjska, swą intensywną i wielostronną działalność rozwijająca już w początkach siedemnastego wieku. Popularność elementów kultury indyjskiej wzrastała również dzięki badaniom gramatyki i leksyki sanskrytu, starożytnego języka indyjskiego. Przyczyniło się to szczególnie do poznania historii rozwoju języków należących do indoeuropejskiej rodziny językowej dzięki pracom takich badaczy jak brytyjski językoznawca William Jones, który pierwszy zwrócił uwagę na znaczenie sanskrytu w analizie języków klasycznych, oraz Franz Bopp, którego badania nad sanskrytem doprowadziły do wydzielenia indoeuropejskiej rodziny językowej poprzez odkrycie fleksji23.

Można też upatrywać podobnej roli sztuki chińskiej w genezie rokoka. Chińszczyzna (chinoiseries), niosąca ze sobą elementy i motywy Dalekiego Wschodu (głównie Chin), występowała już w Europie od XVII wieku. Najpełniejszy wyraz znalazła jednak w sztuce rokoka, szczególnie w architekturze wnętrz, a napłynęła pełniej wraz z chińskimi tkaninami, meblami, malarstwem i porcelaną, której eksport do Europy zapoczątkowano w czasach Dynastii Ming (ok. 1620). W czasach dynastii Qing za panowania cesarza Qianlong (1736-1796) powstawała też porcelana o tematyce europejskiej z dekoracją w stylu chińskim eksportowana na Zachód. Zdobiono ją scenami wzorowanymi na rycinach sprowadzanych do Chin przez misjonarzy jezuickich (stąd nazwa porcelana jezuicka). Do najpopularniejszych należały motywy chrześcijańskie, np. ukrzyżowanie, choć wykorzystywano także wzory mitologiczne, masońskie. Wszystko to było przeniknięte stylem chinoiseries. Asymetrii panującej w tym czasie Europa nigdy przed tym nie znała i ta charakterystyczna cecha z okresu między 1740 a 1780 rokiem, kształtująca ówczesną sztukę ma bezsprzecznie chińską proweniencję $e^{24}$.

Powstanie kolejnego stylu, empire, wiąże się głównie z panowaniem Napoleona I oraz z odkryciem Pompei, ogólnie zaś mówiąc, wpływem antyku. Proste

${ }^{23}$ F. Bopp, Über das Coniugationssystem der Sanskritssprache in Vergleichung mit jenem der griechischen, lateinischen, persischen und germanischen Sprache, Frankfurt am Main 1816; T. Milewski, Z zagadnień językoznawstwa ogólnego i historycznego, Warszawa 1969; R. Colin, Archeologia i język, Warszawa-Poznań 2001, s. 31-32.

24 Porcelana, [w:] Britannica Edycja polska, t. 34, Poznań 2003; R. Hamann, Geschichte der Kunst, t. 2, Berlin 1955, s. 657-708; Rokoko, [w:] Encyklopedia Powszechna PWN, t. 5, Warszawa 1996. 
prowadzenie linii stylistycznych ornamentyki, mebli, układu przedstawień obrazowych znajduje swój początek w Pompejach. W architekturze zaznacza się silny wpływ starożytnej sztuki greckiej, a zwłaszcza rzymskiej. Widoczna jest też duża ilość przedmiotów egipskich. Uderza także monumentalizm, ścisła symetria i surowość form architektonicznych, liczne przedstawienia figuralne, symbole, atrybuty władzy, obfitość ornamentyki. Formy empire przyjęły się powszechnie w połowie XIX wieku w całej Europie, zwłaszcza w Polsce i Rosji.

Sztuka XIX wieku po roku 1830 była tylko imitacją, związkiem najrozmaitszych elementów stylistycznych. Toteż ówczesna twórczość artystyczna doczekała się bardzo krytycznych ocen. Nie rozwinęło się wtedy bowiem żadne nowatorstwo, żadne przekształcenie, wewnętrzne zawłaszczenie, słowem - jakiś własny, odrębny styl.

$\mathrm{XX}$ wiek niesie z sobą innowację stylistyczną. Punktem wyjściowym jest japoński drzeworyt, co można zauważyć u Moneta, Cezanne’a, van Gogha. W sposób widoczny oddziaływać wtedy zaczyna abstrakcyjna sztuka prehistoryczna poprzez sięganie do wzorów malarstwa neolitycznego z południowej Hiszpanii, geometrycznej sztuki greckiej oraz do zwięzłego stylu Sumerów. U Picassa, u Klee, u Miró, Baumeistra, wreszcie u Fernanda Légera wyraźnie widoczny jest wpływ prehistorycznego, abstrakcyjnego stylu ${ }^{25}$.

Gotowość przejmowania przez młodych artystów form sztuki prehistorycznej działa pobudzająco na pasję poszukiwawczą archeologów, którzy odkrywają malarstwo ścienne w jaskiniach (Altamira, Trois Frères, Lascaux) i szczelinach skalnych. Powstaje niezwykły, duchowy związek artystów i badaczy, co jest niewątpliwie źródłem twórczych ekspresji.

Te istotne pytania o sens bytu ludzkiego, a także niezmiernej wagi dylematy początków i stałych przemian w rozwoju doznań estetycznych istot ludzkich wydają się niezmiernie ważnymi źródłami pełnego zaangażowania w rolę badań najstarszej przeszłości przez nas współczesnych. Przybliżają się nam wtedy dyskursywne związki między współczesnością i pradziejami, związki, które nas, współcześnie żyjących, głęboko wzruszają, przejmują i inspirują. Są to niewątpliwie węzłowe procesy naszych czasów, ponieważ dotyczą korzeni bytu i zarazem niosą ze sobą świadomość celów, do których ludzkość dążyć będzie w przyszłości.

25 M. Porębski, Dzieje sztuki w zarysie, t. 1: Od paleolitu po wieki średnie, Warszawa 1976; M. Brezillon, Encyklopedia kultur pradziejowych, Warszawa 2001; H. Roth, Kunst und Handwerk in frühen Mittelalter, Stuttgart 1986. 


\section{Bibliografia}

Baczko B., Rousseau - samotność i wspólnota, Warszawa 1964.

Białostocki J., Sztuka cenniejsza niż złoto, Warszawa 1974.

Bibby G., Faustkeil und Bronzeschwert, Hamburg 1957.

Biblia Święta, to jest Pismo Święte Starego i Nowego Testamentu, Warszawa 1971.

Bopp F., Über das Coniugationssystem der Sanskritssprache in Vergleichung mit jenem der griechischen, lateinischen, persischen und germanischen Sprache, Frankfurt am Main 1816.

Brezillon M., Encyklopedia kultur pradziejowych, Warszawa 2001.

Bukowski Z., Dąbrowski K., Świt kultury europejskiej, Warszawa 1971.

Childe V.G., The Dawn of European Civilization, London 1950.

Colin R., Archeologia i język, Warszawa-Poznań 2001.

Collins D. (red.), The Origins of Europe, London 1975.

Diakonow I., Opowieść o Gilgameszu, [w:] Wschód Starożytny, W.W. Struwe (red.), Warszawa 1956, s. 133-138.

Domański J., Erazm i filozofia, Wrocław 1973.

Haeckel E., Die Anthropogenie, 1874.

Hamann R., Geschichte der Kunst, t. 2, Berlin 1955.

Hezjod, Prace $i$ dnie, Wrocław 1952.

Huntington S.P., Zderzenie cywilizacji i nowy kształt ładu światowego, Warszawa 2001.

Huxley Th.H., Stanowisko człowieka w przyrodzie, Kraków 1874.

Jaspers K.Th., Vom Ursprung und Ziel der Geschichte, Basel 1949.

Kleibl J., Skąd przychodzisz, Adamie?, Katowice 1981.

Kosidowski Z., Gdy Słońce było Bogiem, Warszawa 1956.

Lysen A., Hugo Grotius: Essays on His Life and Works, Leyden 1925.

Melanchton Ph., Epitome doctrinae christianae, Wittenberge 1524.

Meyer E., Geschichte des alten Aegyptens, Berlin 1887.

Milewski T., Z zagadnień językoznawstwa ogólnego i historycznego, Warszawa 1969.

Moore R., Skamieniałymi śladami człowieka, Warszawa 1966.

Platon, Państwo prawa, Kęty 1999.

Porcelana, [w:] Encyklopedia Britannica. Edycja polska, t. 34, Poznań 2003.

Porębski M., Dzieje sztuki w zarysie, t. 1: Od paleolitu po wieki średnie, Warszawa 1976.

Pozdniejewa L., Mity Chińczyków starożytnych, [w:] Wschód Starożytny, W.W. Struwe (red.), Warszawa 1956, s. 208-214.

Rokoko, [w:] Encyklopedia Powszechna PWN (Nowa), t. 5, Warszawa 1996.

Roth H., Kunst und Handwerk in frühen Mittelalter, Stuttgart 1986. 
Rousseau J.-J., Rozprawa o pochodzeniu i podstawach nierówności, Warszawa 1956.

Schiller F., Etwas über die erste Menschengesellschaft, Jena 1790.

Swieżawski S., U źródeł konfliktu nowożytnego przyrodoznawstwa z filozofia scholastyczna, Lublin 1948.

Tönnies F., Tomasz Hobbes, Warszawa 1903.

Weremiej F., Śladami zagubionych ogniw, Warszawa 1977.

Wergiliusz, Bukoliki. Georgiki, Wrocław 1953.

\begin{abstract}
The article deals with one of the most important questions in the history of humanity: why we are here. The author provides a wide overview of the evolution of human thought around the issue of our origins. We continuously have been asking ourselves the same question throughout our history, but it lead us to different conclusions. The essence of life is inseparably linked with the reason of our existence. The effect of which is visible not only in philosophy or sociology, but also in arts. While philosophy tries to describe this essence by thought, art tries to describe it by form and shape. While there is no philosophy without relation to the genesis of humanity, there is no art without emotions. This is why the humans are so curious to discover the past both by thought and form. We simply try to answer this one particular prehistoric question.
\end{abstract}

Keywords: human origins, philosophy, abstract art, values, human subjectivity 